\title{
Communication Pattern and Conflict in Agricultural Extension
}

\author{
Z. Kartika Ekasari ${ }^{1}$, S. Ali M. Saleh ${ }^{2}$, Kamaruzaman Jusoff ${ }^{3}$, Darmawan Salman ${ }^{2}$, Akhsan $^{2}$, Andi Kasirang ${ }^{4}$, \\ Muhammad Arsyad ${ }^{2}$, Amrawaty A. Amidah ${ }^{5} \&$ Letty Fudjaja ${ }^{2}$ \\ ${ }^{1}$ Sekolah Tinggi Penyuluhan Pertanian, Gowa, Indonesia \\ ${ }^{2}$ Department of Agriculture Socio-economics, Faculty of Agriculture, Hasanuddin University, Makassar, \\ Indonesia \\ ${ }^{3}$ Department of Forest Production, Faculty of Forestry, Universiti Putra Malaysia, Serdang, Malaysia \\ ${ }^{4}$ Department of Agriculture Socio-economics, Faculty of Agriculture, Universitas Islam Makassar, Indonesia \\ ${ }^{5}$ Department of Animal Husbandry Socio-economics, Faculty of Animal Husbandry, Hasanuddin University, \\ Makassar, Indonesia \\ Correspondence: Kamaruzaman Jusoff, Department of Forest Production, Faculty of Forestry, Universiti Putra \\ Malaysia, 43400 UPM Serdang, Selangor, Malaysia. Tel: 60-19-227-9507. E-mail: kjusoff@yahoo.com
}

Received: January 9, 2013 Accepted: March 22, 2013 Online Published: April 27, 2013

doi:10.5539/ass.v9n5p27 URL: http://dx.doi.org/10.5539/ass.v9n5p27

\begin{abstract}
This paper deals with communication patterns and conflict in agricultural extension. A strong assumption is that, extension could be expected to enhance agricultural and rural development, but an appropriate communication pattern and conflict in extension remains unsolved. Therefore, the objectives of this paper are three-folds, namely (a) to identify the social processes among actors in implementation of social engineering-based extension and social learning-based extension, (b) to map the communication patterns in agricultural extension, and (iii) to analyze the conflicting functions in agricultural extension. This study uses a Comparative Case Studies Method by focusing on social engineering and social learning in agricultural extension, using a Purposive Sampling Technique. The sample consists of government oficial (including extension officer), prívate sector, researcher and farmer groups. The results show that (i) social process among actors in agricultural extension based on social engineering is more project-oriented (dissociative), while social process in social learning-based extension tends to be cooperation-oriented due to the same interest in achieving goal of programs, especially skill and knowledge improvement (associative), (ii) communication in social engineering-based extension is a linier pattern (top down), while communication in social learning-based extension is using a convergent (participatory) pattern, (iii) conflict in agricultural extension based on social engineering is generally latent (hidden) and will eventually explode and impede extension, impacting group unsolidarity, while in extension based on social learning, conflict generally are on the surface (manifest), and the accommodation is one way to solve. A major implication of these findings is the stepping up of agricultural extension (based on social learning process) which becomes a push factor towards independency group in finding new innovation. The research suggests that social learning-based extension should be developed as a potential way to sustain an important role of extension in agricultural and rural development.
\end{abstract}

Keywords: communication, agricultural extension, social learning, social engineering

\section{Introduction}

Agricultural extension systems world-wide are going through necessary renewal processes and it is sti 11 an open question what role the public sector are going to play regarding extension in the future (Haug, 1999) including extension's role in advancing both development and women's empowerment (Rivera \& Corning, 1990). Agricultural extension has contributed to the achievement of various agricultural development programs, although executed with a top down approach that seem to be forced. The presence of farmers impressed as object development only, executing the instructed things, causing a very high dependency of farmers to the extension officer. This is a probable reason why Ozor and Cynthia (2011) stated that, a change in the extension service agenda to accommodate the challenges currently posed by climate change by adopting new roles identified in the study and the need for increased research and innovation for sustainable adaptation to climate change. This is 
line with Arsyad's findings (2010) that, the higher the frequency of getting information of technology/agriculture extension, non-agriculture jobs information and price information for input-output in agriculture, the higher the crops production (agricultural income) as well as non-agriculture income will be gained, the more total household income will have, which contributes to poverty alleviation. This implies that stepping up agricultural and non-agricultural extension services, could also significantly reduce rural/agriculture poverty (Arsyad \& Kawamura, 2010). Put it in other words, even though agriculture (having extension services) is not a single factor to alleviate poverty, it is a fact that about $70 \%$ of the poor people (Indonesian case) works in rural agriculture. It means that, improving agriculture sector including extension services is a potential way to reduce rural poverty (Arsyad \& Ali, 2009). It can enhance the rural livelihood economy and has changed the way in which the majority of the rural agrarian communities view their farming enterprise (Mapila et al., 2010) as one of socio-economic development goals.

Paradigm shift from technology transfer system to participatory extension has occurred along with the development of models and persuasive communication systems-dialogic, farmers and their families can manage farming began with a conscious and able to do the right choices of alternatives. The participation of farmers actively are learning process to produce and utilize information, build a network of cooperation with local communities to strengthen the institutional system is a provision to change the way of life and increase their income (Hamilton, 1995). However, Marsh and Pannell (2000) identified that, the delivery of extension has been strongly influenced by changing administrative structures and a change in the paradigm within which the extension community operates. There is, therefore, an alarming need to improve agricultural extension activities with the involved farmers through training (Tesfaye et al., 2010), including to plan activity for improving agribusiness productivity, to implement and obey agreement with other institution and to apply technology, information and team work (Rustam, 2009). It is a fact that along with science and technology development in recent decades has driven new innovation, including in agriculture. Through a variety of scientific research, has now discovered and produced many new agricultural technologies. Some of the findings of technology have been disseminated to the farmers to increase farming yield. However, most of these technologies have not been or are not adopted by the farmers, despite various efforts, including extension, has been made to assure its usefulness for improving the quality of life needs. However, Rola and Jamias (2002) identified that, major advances in farm technologies and the globalization of agricultural markets offer promising opportunities for improving the quality of life of farmers in developing countries. A major issue with these, however, concerns the effective and efficient delivery of the knowledge and information on these new advances and markets to dispersed farmers, so that they can capitalize on these developments.

Ideally, development of farming technology placed on a frame to improve the performance of rural economic development. The notion that agriculture in rural development framework has been implemented is not entirely correct to reality. The current production systems at farm level are less able to produce highly competitive agricultural products to meet the needs of both domestic and export markets. This is because only technology (physical) is forced to be transformed without transforming overall society. This brings an important message that, technological transformation should be comprehensive and able to follow the dynamics of peasant society, rooted in the aspirations of the farmers, and involving all stakeholders.

Implementation of agricultural extension with a variety of approaches and methods will certainly involve a variety of actors pose complexities, such as complexity of the program, actors, and the complexity of interactions between actors involved in agricultural extension activities, and if it is not coordinated well will cause disharmony that has the potential for conflict. However, Coser (1956) emphasized that in essence, the conflict has always existed in various forms of human life and conflict has a function in the life of society. Disharmony among the actors involved in the implementation of agricultural extension activities, due to the different understanding between them. It will cause distortion and affect the actions which will in turn result in disharmony relationships between actors. Relationship disharmony caused by disagreements communication will potentially lead to conflict in communication that could hinder implementation of agricultural extension.

Given the current situations, communication pattern and conflict management in agricultural extension becomes serious issue in developing countries, in which Indonesia is no exception. This is a reason why the research is directly directed to examine the linkage between communication patterns, type and conflict management in agricultural extension. Three specific purposes of the paper are; (i) identifying social processes among actors in implementation of social engineering-based extension and social learning-based extension, (ii) mapping communication patterns in agricultural extension, and (iii) analyzing conflicts function in agricultural extension. 


\section{Method}

The research was conducted in Maros District, South Sulawesi Province, Indonesia. The research employed a Comparative Case Studies Method by focusing on social engineering and social learning in agricultural extension, using a purposive sampling technique. For data collection, three components of informant were interviewed as follows:

1) the government extension services in provincial, district and sub-district levels,

2) private components (agricultural businessman, trader),

3) researcher components (university, research institute),

4) farmers components (individual and farmers groups).

For comparison purposes between the farmer groups, Farmer Group "Tunas Jaya" (for social engineering) and Farmer Group "Bonto Rea I" (for social learning) were chosen. The types of data collected comprise of the following:

1) social process, regarding how the interaction between the actors involved in agricultural extension both based on social engineering and social learning. In addition, it examined the shape/type of social processes (associative or dissociative),

2) communication pattern, regarding how communication patterns starting from the source to the recipient, whether linear or convergent,

3) type and source of conflict dealing with data on the type of conflict whether latent or manifest.

Data on the source of conflict or conflict triggers concerns whether it comes from the source, message, channel, or the recipient. Data on conflict function, identifying whether the conflict will strengthen or weaken the sustainability goals that may hinder the implementation of agricultural extension.

\section{Results}

\subsection{Types of Social Process in Agricultural Extension: Social Engineering versus Social Learning}

The central point of the study relies on the fact that, social network analysis takes relations as well as individuals as primary subjects of study. Individuals in a network have relations that allow for the exchange of tangible (information and services) and intangible (social support and authority) goods. When two individuals are connected by a set of social relations, a tie is formed. The strength of a tie varies with the frequency, duration, intensity, and reciprocal quality of that relation. Given set of actors and a set of ties, the structure of a social network can be identified. Individuals can be any actor or group of actors, from animals to entire nation states. Ties can be positive or negative (friendship or enmity) and can be symmetrical (the tie between A and B is the same as the tie between B and A) or asymmetrical (the tie between A and B is different from the tie between B and A). These sets of relations determine the relative social positions of actors in the system (Hafner-Burton and Montgomery, 2006). One of the important findings in the research site is that, both models of agricultural extension (social engineering-based and social learning-based) prove that each farmer joining the farmer group basically because of possibility to make good progress and development. In these farmers group, each farmer has opportunity to learn, understand and work with other farmers. The type of relationship (social process) that is shown among farmers in a group can be in the form of cooperation, competition, accommodation and conflict.

In order to solve the conflict, there is a need to do re-inventory the rights of local community that have to be accommodated by any formal decision made by the government (Ali et al., 2009). This is one of the comparative advantages of agricultural extension in social-learning based. Bungin (2007) also revealed that, cooperation arises when people realize that they have the same interests and at the same time have enough knowledge and self-control to meet these interests, awareness of the same interests and the organization are important facts in a useful cooperation.

In the field, it was found that, many types of relationships that occur in the Farmer Group "Bonto Rea I", namely mutual cooperation and mutual assistance in order to achieve goals. They have awareness for a common goal to solve the problems and meet the needs of farmers in terms of co-operation. In addition, they also have togetherness and awareness among actors, so that the continuity of relationship can be more harmonious among them. However, it should be noted here that, interdependent relationship may result in conflict. This occurs when the individual components of the organization have an on their own interest or purpose, without sense of cooperation. This reminds us that relationship or social interaction naturally, might have positive and negative sides. 


\subsection{Communication Patterns in Agricultural Extension}

Although communication patterns are not easily controlled, more potential exists to change the patterns that is strongly depends on the type of group or society. It is important to note that, in agricultural extension approach based on social learning in Farmers Group "Bonto Rea I", the communication patterns are two-way, and each actor can act as a source and receiver of information. Farmers are not the only actors who have received any information provided by the extension services, but also farmers serve as a source of information by other actors based on the experience they have (participatory pattern). This is in line with David Kolb statements in Experiential Learning Theory, that knowledge is created through the transformation of experience. Knowledge results from the combination of grasping and transforming experience (Kolb et al., 1999). In farmer level, it was found that the farmers are experiencing experiment and applying to their farming. The good impact of this learning process is that, the farmers experience is communicated among them quickly, and replicated by the other actors. This is a reason why Kolb et al. (1999) deemed that, in transforming or processing experience some of us tend to carefully watch others who are involved in the experience and reflect on what happens, while others choose to jump right in and start doing things.

Model of learning based on experience from farmer to farmer was obtained through a process of imitation in social learning-based extension, is more effective by considering knowledge and skill of the current extension officers (so called PPL). Sometimes, it was found that PPL have a difficulty to help farmers in making farming decisions. At the same time, farmers know their purpose, the amount of capital, labor, and others resources. Therefore, farmers knowledge or experiences and PPL have put together to develop the most productive farming systems for farmers and their families. This can be done by a dialogue, in which PPL listening to the farmers and not trying to convince about how they should develop their farming systems. Therefore, farmers can also be used as a source of information for the governments, researchers and PPL. In addition, by having this communication pattern, the farmers will have a good motivation in doing farming as well as skill transmission.

\subsection{Types, Source and Function of Conflict in Agricultural Extension}

According to Parson (1937) in the Structural-Functional Theory, society is a complex system consisting of parts which are interconnected and interdependent each other and each section is a significant influence on other parts. Conversely, if there are parts among them that do not perform function properly, then the system will not be there or will go away, conflicts will occur, in other words. This statement is different from Coser (1956) that, even in the presence of conflict, it can help maintain the social structure. Conflict is a normal event in the life of community, because of differences in values, perceptions, habits, and interests among different groups of people are potential factors that could be the conflict trigger. The conflicts have positive and negative sides. In positive dimensions, the conflict becomes an important part to the social change realization, which is more meaningful to resolve differences and building dynamics. While the negative side, the conflict may pose risks for the society, for example, the occurrence of social disharmony and can be a crisis or chaos trigger.

One of the conflict types occurs in the field is conflict between farmers and researchers caused by farmers un-satisfaction to PPL and researchers. As a result, farmers do not want to follow the activities and group meetings and prefer to separate and indirectly forming small groups. These farmers who joined to the small group are those people who feel overlooked by the government and they are always trying to find their own information and useful knowledge and skill for their farming development. This indicates that, conflict has a positive function to develop farmer group members.

Another type of conflict arises due to a jealousy among the actors in agricultural extension agents, impacting on the groupings among the group members themselves and their activity in the group. Members of the group who have land or homes close to each other, always involved in social process and communication. The same thing happens on group members who closes to the chairman and group board, seems to form his own group. Attitudes and behavior are exhibited by some farmers show that, in fact among the actors who interact already keeping the seeds of conflict, but generally it remains on the surface and occurs only because of the misconception. Therefore, the conflict will make the group in stronger situation. This is in line with Coser (1956) where conflict can actually strengthen group solidarity. In addition, conflict could lead to isolated communities become active participants. The presence of conflict does not need to be viewed as a troubling event but rather with the appearance of conflict can result in a change in and be more dynamic.

\section{Discussion}

It is a fact that in the implementation of agricultural extension based on social learning in Farmer Group "Bonto Rea I", competition and conflict among them has mostly been positive, in the sense that the existence of competition and conflict could further enhance solidarity and further improve motivation to move forward 
together. While the implementation of agricultural extension based on social engineering as practiced by Farmer Group "Tunas Jaya", it was found that interactions in the form of cooperative by each actor is always accompanied by a sense to compete and try to undermine each other, thus leading to conflicts which resulted in divisions among farmers. Another serious effect is that, the two warring parties will show hostility and tend not to get involved in group activities. These factors led to the lack of interaction intensity, resulting in among the actors seem to walk on their own, and the occurrence of acts such as defiance, avoidance and hostility. All these indicate that, the impact of social interaction is strongly depends on the goal and motivation of actors in the group. If the interaction has mutual understanding among groups, there is a high possibility of having good solidarity and sense of belonging among individual and groups.

The results on the type of social processes in agricultural extension especially social learning-based shows that the real partnership between farmers was simply because they are looking for mutual learning and understanding among them. This is because the strength of relationship among them, in terms of family relationship, neighbor, proximity of land and have the same job. All type of cooperation made by the actors in implementation of agricultural extension activities are based on the concerns and common goals and interests, which will in turn strengthen and expand cooperation network. If there is competition and conflict between them, the accommodation is one solution for those who have a conflict. Even though providing agricultural extension can strongly encourage smallholders income meaning poverty reduction (Arsyad \& Kawamura, 2009), agricultural extension agents are also expected to play a key role in linking smallholder to agricultural scientist and researchers (Haile \& Abebaw, 2012) and extension's role in advancing both development and women's empowerment (Rivera \& Corning, 1990). This leads us to argue that, maximizing the role of PPL in agricultural extension could help smallholder in institutional development, improving welfare in other words (Arsyad et al., 2012). The phenomena seen in the Farmers Group "Tunas Jaya" that is based on social engineering, the only source of information for the farmers dominantly came from PPL as government extension officer, so that almost no opportunity for the farmers and PPL to inform the farmers innovations, creating linier pattern communication. Study of Mapilla et al. (2010) recommended that, there is deliberate need for development agents, practitioners and promoters to create an enabling environment, in which both rural elites and non-elites are able to thrive, participate and benefit fully within rural farmer organizations by changing the prevailing negative self perceptions. Besides, there is significant relationship between frequency of communication channels use by farmers and their educational level, sex, farm size and farming experience (Okwu \& Daudu, 2011).

Conflict in agricultural extension both based social learning as well as those based on social engineering can be viewed from the positive and negative sides, depending on how each of the actors perceive and manage conflict. This is in line with Coser (1956) that the conflict is not always negative, the processes of conflict often has positive consequences. The conflict can be positive and close stronger solidarity among the members of the group to maintain the integrity of the group, uniting its members, and make the members who less active to participate more in the group.

It was found that, in the Farmers Group "Tunas Jaya", conflict occurs due to seeds are not equally distributed among members and does not match with the timing of seeds distribution, causing most farmers rejected and use the seeds by borrowing and doing his own captivity. The reason why the farmers refuse and prefer to plant their seed themselves, is; first, the already know the quality of seed planted. Second, it can strengthen their relationship among members by borrowing seed each other. It is general phenomenon that, the refusal by the farmers to some government where the programs are conducted in a top-down mechanism.

Another positive impact of conflict is differentiation in perception among groups. At that time, an increase in positive attitudes to the group creates increasing in internal solidarity, group cohesiveness, commitment and aggressive leadership. This indicates that conflict could become a good instrument to increase participation of all members in the group. In other words, this fact can transform conflict into the harmonious intergroup relations. The conflict in Farmers Group "Bonto Rea I" either between members, members and the boards, between boards, even among farmers with institutions outside the group is basically due to lack of understanding among the different actors in extension activities. However, they could manage the conflicts among them. Therefore, there is no conflict in the Farmers Group "Bonto Rea I" which eventually leads a dispute.

A major implication of this finding is that, managing conflict could become a potential way to increase a good cooperation in sustaining communication of the group in agricultural extension services. One of the efforts undertaken in the group, so that there is no potential problem such as latent conflict is that, the parties are always trying to mediate and attempt to resolve the issue. In addition, the presence of rivalry and jealousy can be motivation and strong spirit to continue a better social change. Therefore, it is necessary to have a mutual understanding and mutual respect in terms of cooperation both within and outside the group. Unlike the case in 
Farmers Group "Tunas Jaya", the conflict is generally due to the different goals and interests and there is no attempt to defuse the conflict, so that the conflict is usually latent which may result in quarrels and hostilities and in turn causing a lethal group. All these indicate that, the conflict that is unwell managed could hinder development program (due to conflict is un-functioning in a positive way), including agricultural extension sustainability.

\section{Conclusion}

Some principal findings include; (i) social process among actors in agricultural extension based on social engineering is more project-oriented (dissociative), while social process in social learning-based extension tends to be cooperation-oriented due to the same interest in achieving goal of programs, especially skill and knowledge improvement (associative), (ii) communication in social engineering-based extension is a linier pattern (one-way or top down communication) in which farmers have no opportunity to find and apply their new innovations. This pattern also lead extension officer (called PPL) has no opportunity to pass any innovation generated by the farmers and even they only implement the recommendation are packed nationally (top down). Meanwhile, in social learning-based extension is using a convergent pattern (participatory communication), in which each actor is free to find and communicate their innovations, (iii) conflict in agricultural extension based on social engineering is generally latent (hidden) and will eventually explode and impede extension, impacting on group unsolidarity, while in extension based on social learning, conflict generally are on the surface (manifest), and the accommodation is one way to solve. A major implication of these findings is stepping up agricultural extension based on social learning process, could become push factor towards independency group in finding new innovation. The research suggests that social learning-based extension should be developed as a potential way to sustain an important role of extension in agricultural and rural development.

\section{References}

Ali, M. S. S., \& D. Salman, M. (2009). Relations of Government, Company and Community in Land Conflict. Paper Presented at the $6^{\text {th }}$ International Symposium on Participatory Research for Poverty and Conflict Resolution. Afrasian Centre for Peace and Development Studies, Ryukoku University, Kyoto.

Arsyad, M., \& Ali, D. (2009). Does Agriculture Really Alleviate Poverty? Lesson from Indonesian Economic Evidence. Ryukoku Journal of Economic Studies, 48(3), 1-21.

Arsyad, M., \& Kawamura, Y. (2009). A Poverty Causal Model of Cocoa Smallholders in Indonesia: Some Initial Findings from South Sulawesi. Ryukoku Journal of Economic Studies, 49(2), 1-27.

Arsyad, M., \& Kawamura, Y. (2010). Reducing Poverty of Cocoa Smallholders in Indonesia: Is Agricultural Economic Activity Still the Pioneer? Economics and Finance in Indonesia, 58(2), 217-238.

Arsyad, M. (2010). The Dynamics of Cocoa Smallholders in Indonesia: An Application of Path Analysis for Poverty Reduction (in Abstracts of Doctoral Thesis on the Indonesian Economy). Bulletin of Indonesian Economic Studies, 46(2), 251-254.

Arsyad, M., Nuddin, A., \& Yusuf, S. (2012). Strengthening Institutional Towards Smallholders Welfare: Evidence from Existing Condition of Cocoa Smallholders in Sulawesi, Indonesia. Ryukoku Journal of Economic Studies, (In print).

Bungin, B. (2007). Sosiologi Komunikasi; Teori, Paradigma, dan Diskursus Teknologi Komunikasi di Masyarakat. Kencana Prenada Media Group, Jakarta (In Bahasa Indonesia).

Coser, L. A. (1956). Social Conflict and the Theory of Social Change. The British Journal of Sociology, 8(3), 197-207. http://dx.doi.org/10.2307/586859

Hafner-Burton, E. M., \& Montgomery, A. H. (2006). Power Positions: International Organizations, Social Networks, and Conflict. Journal of Conflict Resolution, 50(1), 3-27. http://dx.doi.org/10.1177/0022002705281669

Haile, M. G., \& Abebaw, D. (2012). What Factors Determine the Time Allocation Agricultural Extension Agents on Farmers' Agricultural Fields? Evidence from Rural Ethiopia. Journal of Agricultural Extension and Rural Development, 4(10), 318-329.

Hamilton, N. A. (1995). Leaning to Learn with Farmers (1st ed.). Wageningen.

Haug, R. (1999). Some Leading Issues in International Agricultural Extension: A Literature Review. The Journal of Agricultural Education and Extension, 5(4), 263-274. http://dx.doi.org/10.1080/13892249985300061

Kolb, D. A., Boyatzis, R. E., \& Mainemelis, C. (1999). Experiential Learning Theory: Previous Research and 
New Directions. Department of Organizational Behavior, Weatherhead School of Management, Case Western Reserve University, Cleveland.

Mapila, M. A. T. J., Makwenda, B., \& Chitete, D. (2010). Elitism in the Farmer Organization Movement in Postcolonial Malawi. Journal of Agricultural Extension and Rural Development, 2(8), 144-153.

Marsh, S. P., \& Pannell, D. (2000). Agricultural Extension Policy in Australia: the Good, the Bad and the Misguided. Australian Journal of Agricultural and Resource Economics, 44(4), 605-627. http://dx.doi.org/10.1111/1467-8489.00126

Okwu, O. J., \& Daudu, S. (2011). Extension Communication Channels' Usage and Preference by Farmers in Benue State, Nigeria. Journal of Agricultural Extension and Rural Development, 3(5), 88-94.

Ozor, N., \& Cynthia, N. (2011). The Role of Extension in Agricultural Adaptation to Climate Change in Enugu State, Nigeria. Journal of Agricultural Extension and Rural Development, 3(3), 42-50.

Parsons, T. (1937). The Structure of Social Action: A Study in Social Theory with Special Reference to a Group of Recent European Writers. New York: The Free Press.

Rivera, W. M., \& Corning, S. L. (1990). Empowering Women through Agricultural Extension: A Global Perspective. Journal of Extension, 28(4), 24-35.

Rola, A. C., \& Jamias, S. B. (2002). Do Farmer Field School Graduates Retain and Share What They Learn? An Investigation in Iloilo, Philippines. Journal of International Agricultural and Extension Education, 9(1), 65-76.

Rustam, R. (2009). Effect of Integrated Pest Management Farmer Field School (IPMFFS) on Farmers' Knowledge, Farmers Groups' Ability, Process of Adoption and Diffusion of IPM in Jember District. Journal of Agricultural Extension and Rural Development, 2(2), 29-35.

Tesfaye, T., \& Karippai, R. S. (2010). Farmers Training Effectiveness in Terms of Changes in Knowledge and Attitude: The case of Holeta, Melkassa and Debre zeit Agricultural Research Centres, Ethiopia. Journal of Agricultural Extension and Rural Development, 2(5), 89-96. 